\title{
Achievements of a Pilot Solar Powered Irrigation Project in Bangladesh
}

\author{
Sania Binte Mahtab ${ }^{1}$, Abrar Morshed ${ }^{2}$ \\ Assistant Professor, Department of Water Resources Engineering, \\ Bangladesh University of Engineering and Technology, Dhaka, Bangladesh ${ }^{1}$ \\ Graduate, Department of Computer Science and Engineering, Ahsanullah University of Science and Technology, \\ Dhaka, Bangladesh ${ }^{2}$
}

\begin{abstract}
Bangladesh is a country of 160 million people where solar powered irrigation systems have proven to be a viable alternative among other renewable energy sources. The flat terrain and abundant sunshine are the two main factors behind the increasing demand for solar powered systems in this region. In the traditional irrigation system diesel engines or the electricity from the main grid is usually used both of these methods are not friendly to the environment. The use of solar energy to pump ground water is a indigenous low cost solution that is helping the farmers of this middle income country immensely. On the other hand proper regulations should be implemented to regulate the use of water resources in order to avoid depletion of ground water resources. the pilot project also aims to supply the unused electricity during the off peak season to the national grid.
\end{abstract}

Keywords: Solar powered irrigation systems, renewable energy, sustainable development

\section{INTRODUCTION}

Solar based irrigation systems are innovative and environment friendly solution for the agriculture intensive economy of Bangladesh. The pilot project which is situated in the drought prone Northern part of the country is intended to provide irrigation facility to off-grid areas, reducing carbon emission and thereby reducing dependency on fossil fuel. Bangladesh has shown significant performances in recent past maintaining an average of $6.01 \%$ GDP growth since 2010[1]. In Bangladesh with nearly 160 million population and about two-third of the total population is directly or indirectly involved with agriculture. Agricultural sector of the country contributes to about $16 \%$ of the gross domestic product. In average, 1.9 million people are being added every year which creates additional rice demand of over 350 thousand metric tons. On the other hand, due to rapid urbanization and industrialization, the country is significantly losing its cultivable land. In 2015, the cultivated land for rice was about 10.7 million hectares which will be reduced to 10.28 million hectares by next 5 years. As one of the countries to be hit the hardest with adverse affects of climate change it is already facing extreme climatic changes. [2] Analyzed the changes in historical precipitation extremes over Bangladesh which is the deciding factor for the requirement of irrigation water in different parts of the country. Due to climate change the rainfall pattern is changing in a way that the areas receiving maximum rainfall will receive even greater amounts of rainfall in the future and vice versa for the drought prone regions of the north western parts of Bangladesh. In Bangladesh, still natural gas accounts for almost $72.42 \%$ of total electricity generation fuel mix, and only $2.5 \%$ from renewable energy sources in the fiscal year 2013-2014 [3]. Thus to utilize the country's immense renewable energy potential, more and more initiatives must be undertaken. At present, about 1.43 million diesel-based pumps and 320,557 electricity-based pumps are in operation for irrigation, which consume more than 1.06 million tons of diesel and near about $1400 \mathrm{MW}$ electrical power, respectively. The solar irrigation pumps emit about 7 million tons of carbon dioxide every year which significantly pollutes the environment. In April this year, the World Bank group has approved \$55 million to help the country expand in clean and renewable energy sector. The financing will also help increase use of solar irrigation pumps, a low-cost technology that is well suited to the country's flat terrain and abundant sunshine. This switch from diesel pumps will decrease greenhouse gas emissions and save foreign exchange by reducing the government's subsidy on diesel imports [4]. Bangladesh is one of the energy starved countries, only $60 \%$ of its population has access to electricity. A huge amount of diesel fuel is required to import to mitigate the country's energy demand as the country has very limited fossil fuel resources. In order to maintain a reasonable diesel price, the government had to subsidy around USD 0.3/L of diesel in recent years. However, the geographical position of Bangladesh is ideal for solar energy utilization which can be harvested from anywhere in the country. The annual solar radiation is as high as $1700 \mathrm{kWh} / \mathrm{m}^{2}$ with the variation of daily average solar radiation of $4-6.5 \mathrm{kWh} / \mathrm{m}^{2}$. Therefore, solar irrigation may be an alternative way to increase production of crops without creating extra pressure on grid power or diesel fuel, and also helps to keep the environment clean. Bangladesh suffers from various climate 


\section{International Advanced Research Journal in Science, Engineering and Technology}

Vol. 5, Issue 9, September 2018

disasters like droughts (the northern part), floods (mainly the central part) and salinity intrusion (the southern part) [5], which further emphasizes the need for a clean and sustainable source of water supply for irrigation in the region where the pilot project is situated. The country's government has taken an initiative to replace 18,700 diesel based irrigation pumps by solar irrigation pumps. IDCOL (Infrastructure Development Company Ltd.), a fully government owned financial institution has given attractive incentives, e. g. providing 50\% subsidy and arranging $35 \%$ soft loan with the aid of donor agencies. Under the program, owners or individual investors require to invest only $15 \%$ of the total cost. Already IDCOL has approved 1032 solar irrigation pumps of which 930 are now in operation. The remaining pumps are expected to come into operation shortly. Also it has a target to finance 1500 solar irrigation pumps by 2018 and 50,000 solar irrigation pumps by 2025 . The only place where caution needs to be practiced in the sustainable use of ground water in areas where solar powered irrigation systems have been installed [6].

\section{METHODOLOGY}

The pilot project's field activities have been running since 2015. The analyzed data were collected via interviewing and systematic report basis. The field operational team and technical team are doing their regular job while frequently generating reports. In First phase, thirty (30) pumps were installed in 2016 in 15 different sites at Badarganj upazila in Rangpur district. Then in second phase and third phase, 93 and 107 solar irrigation pumps were installed in Rangpur and Dinajpur district respectively. Irrigated Command area and number of land owners with beneficiaries in boro season were collected by questionnaire survey basis as shown in Table 1 . The pilot project has a goal to supply the unused electricity generated through the solar panels to the main grid during off-peak seasons as shown in Table-2. This will eventually contribute positively to improve the overall energy crisis of the country. Figure 1 shows a picture of the pilot area from Dinajpur area.

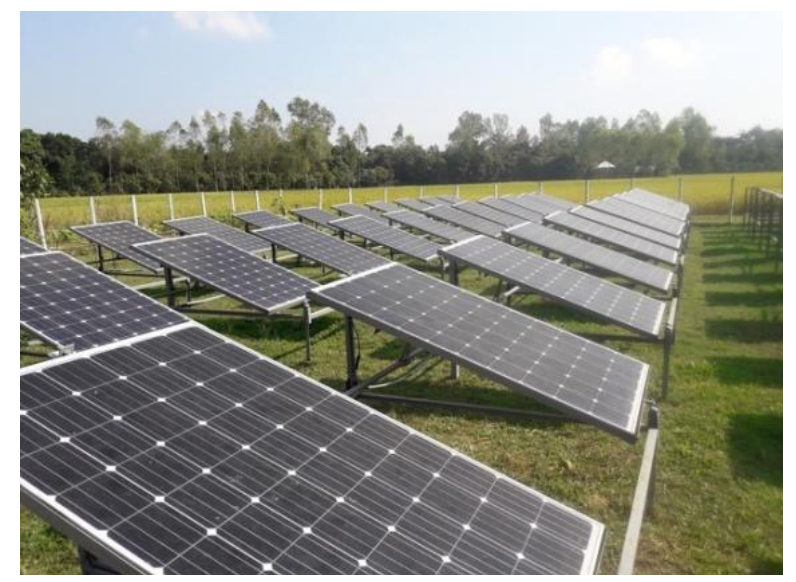

Fig. 1 A picture from the pilot area

Table:I Irrigated Command Area with Beneficiaries (in Boro Season, Year 2018)

\begin{tabular}{|l|l|l|l|l|l|l|l|}
\hline $\begin{array}{l}\text { Project } \\
\text { Name }\end{array}$ & $\begin{array}{l}\text { Pump } \\
\text { Capacity } \\
(\text { Kw) }\end{array}$ & $\begin{array}{l}\text { No. } \\
\text { of } \\
\text { site }\end{array}$ & $\begin{array}{l}\text { Each site } \\
\text { Coverage } \\
\text { Area(acres) }\end{array}$ & $\begin{array}{l}\text { Total } \\
\text { coverage } \\
\text { Area (acres) }\end{array}$ & $\begin{array}{l}\text { Farmers } \\
\text { for each } \\
\text { site }\end{array}$ & $\begin{array}{l}\text { Total } \\
\text { Farmers }\end{array}$ & Total Beneficiaries \\
\hline$(1)$ & $(2)$ & $(3)$ & $(4)$ & $(5)=(3) x(4)$ & $(6)$ & $\begin{array}{l}(7)= \\
(3) x(6)\end{array}$ & $\begin{array}{l}(8)=(7) x 5(\text { Each } \\
\text { Family member })\end{array}$ \\
\hline Phase-1 & $3.75 \times 2=7.5$ & 15 & 25 & 375 & 60 & 900 & 4,500 \\
\hline Phase-2 & $7.50 \times 2=15$ & 93 & 48 & 4,464 & 90 & 8,370 & 41,850 \\
\hline Phase-3 & 15 & 107 & 48 & 5,136 & 90 & 9,630 & 48,150 \\
\hline
\end{tabular}

\section{DATA ANALYSIS}

Table-1 shows that phase-1, phase- 2 and phase- 3 are running and performing well. Also those are irrigating boro crops of average 25 acres, 48 acres and 48 acres farmers land respectively. Around 18,900 farmers included 94,500 beneficiaries are directly now benefited those who used shallow engine (Diesel engine) before starting solar irrigation pumps. All those farmers feel comfortable because now there is no hassle of purchasing fuel to run diesel engines thus saving time for labor. In the whole year, solar irrigation pumps are used only maximum five months (150 days ) but others days ( more than 210 days) there are some scope for supplying unused solar electricity (Electricity generation shown in Table-2) to the local entrepreneurs and also to the national grid. 


\section{International Advanced Research Journal in Science, Engineering and Technology}

Vol. 5, Issue 9, September 2018

Table:II Electricity generation by solar panel during the off peak period (Yearly- 210 days)

\begin{tabular}{|c|c|c|c|c|c|c|c|}
\hline Project Name & $\begin{array}{l}\text { No. } \\
\text { of } \\
\text { Site }\end{array}$ & $\begin{array}{l}\text { Panel } \\
\text { capacity } \\
\text { for each } \\
\text { site }(\mathrm{Kw})\end{array}$ & $\begin{array}{l}\text { Total } \\
\text { capacity } \\
(\mathbf{K w})\end{array}$ & $\begin{array}{l}\text { Actual } \\
\text { capacity } \\
(\mathrm{Kw})\end{array}$ & $\begin{array}{l}\text { Average } \\
\text { Day-light } \\
\text { hour(From } \\
\text { May to } \\
\text { January ) }\end{array}$ & $\begin{array}{l}\text { Total } \\
\text { Electricity } \\
\text { Generation } \\
\text { per } \\
\text { day(Kwh) }\end{array}$ & $\begin{array}{l}\text { Yearly ( for } \\
210 \text { days) } \\
\text { Electricity } \\
\text { Generation } \\
\text { (Kwh) }\end{array}$ \\
\hline (1) & (2) & (3) & $\begin{array}{l}(4 \\
=(2) x(3)\end{array}$ & $\begin{array}{l}(5)= \\
(4) x 70 \%\end{array}$ & (6) & $(7)=(5) x(6)$ & $(8)=(7) \times 210$ \\
\hline Phase-1 & 15 & 15 & 225 & 157.5 & \multirow{6}{*}{$5 \mathrm{hrs}$. } & 787.5 & 165,375 \\
\hline Phase-2 & 93 & 30 & 2,790 & 1,953 & & 9,765 & $2,050,650$ \\
\hline Phase-3 & 107 & 30 & 3,210 & 2,247 & & 11,235 & $2,359,350$ \\
\hline \multicolumn{2}{|l|}{ Sub total } & - & - & - & & $21,787.5$ & $4,575,375$ \\
\hline $\begin{array}{l}\text { Phase-4 } \\
\text { (Ongoing) }\end{array}$ & 250 & 32 & 8,000 & 5,600 & & 28,000 & $5,880,000$ \\
\hline $\begin{array}{l}\text { Under Planning(with } \\
\text { in the Year 2025) }\end{array}$ & 4535 & 32 & 145,120 & 101,584 & & 507,920 & $106,663,200$ \\
\hline Total & - & - & - & - & - & $\begin{array}{l}557707.5 \\
=557 \mathrm{Mwh}\end{array}$ & $\begin{array}{l}\begin{array}{l}117118575 \\
=117,118 \mathrm{Mwh}\end{array}\end{array}$ \\
\hline
\end{tabular}

\section{RESULTS AND DISCUSSIONS}

The solar-powered irrigation systems have a high potential value in terms of sustainability benefits to the agronomy of our country. It could easily decrease dependency on fossil fuel, national Grid of electricity and also reducing carbon emission. It helps to ensure rural economic development of the country and improvement of standard living of the rural people through sustainable and environment-friendly investment. The real benefit goes much deeper that solar irrigation pumps are playing a vital role to improve quality of life for the farmers in Bangladesh. They now have more spare time for their other productive purposes. For irrigation, farmers just notify the lineman (pump operator) of the solar pumps, and water flows to his entire land. By implementing the solar irrigation pump the uncertainty days are gone and will not have any hard labor for ensuring the water supply to his own land for irrigation. Renewable is a viable option for a resource constraint country like Bangladesh. Energy is the building block of modern civilization and a prerequisite for sustainable development [7], but we also have to ensure that the energy is also coming from a sustainable source like solar energy. On its goal to become energy sufficient, the use of solar energy has proved to be very efficient.

\section{ACKNOWLEDGMENT}

The authors would like to express their gratitude to the editors of this journal and the unanimous peer reviewers.

\section{REFERENCES}

[1]. S. B. Amin, S. L. Islam, T. Z. Kamal, and N. N. Mithila, "Prospects and Constraints of Renewable Energy Sector in Bangladesh : An Analytical Exercise," vol. 6, no. 2, pp. 1-12, 2016.

[2]. S. B. Mahtab and S. M. Khan, "Changes in Historical Precipitation Extremes over Bangladesh," Int. Journal of Scientific Engineering and Research, vol. 6, no. 9, pp. 64-68, 2018.

[3]. P. K. Halder, N. Paul, M. U. H. Joardder, and M. Sarker, "Energy scarcity and potential of renewable energy in Bangladesh," Renew. Sustain. Energy Rev., 2015.

[4]. Karaban E and Mahbub M A, "Bangladesh: World Bank Increases Support for Clean Renewable Energy," World Bank News. [Online]. Available: https://www.worldbank.org/en/news/press-release/2018/04/10/bangladesh-world-bank-increases-support-for-clean-renewableenergy. [Accessed: 28-Sep-2018].

[5]. S. B. Mahtab and N. A. Khan, "Sustainable poverty eradication measures : the intertwined relationship of income poverty and water poverty", Proceedings of CSCE Annual General Conf., pp. 1-11, Edmonton, Alberta. 2012.

[6]. C. Emsden, "Positive Prospects for Solar Powered Irrigation Systems," FAO Press Release, 2018. [Online]. Available: http://www.fao.org/news/story/en/item/1114618/icode/. [Accessed: 28-Sep-2018].

[7]. M. T. Islam, S. A. Shahir, T. M. I. Uddin, and A. Z. A. Saifullah, "Current energy scenario and future prospect of renewable energy in Bangladesh,” Renew. Sustain. Energy Rev., vol. 39, pp. 1074-1088, 2014. 


\title{
International Advanced Research Journal in Science, Engineering and Technology
}

\author{
Vol. 5, Issue 9, September 2018
}

\section{BIOGRAPHY}

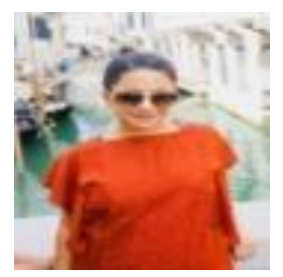

Sania Binte Mahtab received the B. Sc and M. Sc degrees in Water Resources Engineering from Bangladesh University of Engineering and Technology (BUET). She is currently a PhD candidate at the Department of Civil Engineering and Applied Mechanics in McGill University, Canada. She is the recipient of Bibarta Gold Medal in recognition of her contribution to research on Climate Change and Water Resources. She is now working as an Assistant Professor at BUET.

Abrar Morshed is a graduate of Ahsanullah University of Science and Technology from the department of Computer Science and Engineering and is currently working in the renewable energy sector of Bangladesh. 